\title{
Dynamic Impact of Chromium on Nutrient Uptake from Soil by Fluted Pumpkin (Telfairia occidentalis)
}

\author{
Woke Justics Chigonum, Osu Charles Ikenna*, Chukwu Uche John \\ Department of Pure and Industrial Chemistry, University of Port Harcourt, Choba, Nigeria \\ Email address: \\ charsike@yahoo.com (O. C. Ikenna) \\ ${ }^{*}$ Corresponding author \\ To cite this article: \\ Woke Justics Chigonum, Osu Charles Ikenna, Chukwu Uche John. Dynamic Impact of Chromium on Nutrient Uptake from Soil by Fluted \\ Pumpkin (Telfairia occidentalis). American Journal of Bioscience and Bioengineering. Vol. 7, No. 1, 2019, pp. 1-9. \\ doi: 10.11648/j.bio.20190701.11
}

Received: January 21, 2019; Accepted: February 21, 2019; Published: March 27, 2019

\begin{abstract}
Pot experiments were conducted to investigate the impact of chromium on nutrient uptake by fluted pumpkin (Telfairia occidentalis) in soil. The study was conducted with a sandy loam soil for three weeks on a slightly acidic soil. Stratified sampling method was used. Soil samples were collected before and after planting to determine soil nutrient concentrations using Atomic Absorption Spectrophotometer and Hach Spectrometer. The result showed a maximum uptake of $27.5 \%, 17.57 \%, 17.07 \%, 9.76 \%, 18.44 \%$ and $3.66 \%$ for $\mathrm{N}, \mathrm{P} . \mathrm{Mg}, \mathrm{Fe}, \mathrm{Ca}$, and $\mathrm{K}$ respectively. Excellent morphological characteristics were observed at $2.5 \mathrm{ppm}$ chromium concentration with average height, average number of leaves and average distance between nodes as $33.0 \mathrm{~cm}, 10$ and $4.8 \mathrm{~cm}$ in contrast with $21.0 \mathrm{~cm}, 8$ and $2.3 \mathrm{~cm}$ respectively. The impact of chromium concentration showed no specific trend on all nutrients considered, but had varying effects on the uptake of individual nutrient. The result also showed that increasing chromium concentration inhibit the uptake of $\mathrm{Mg}, \mathrm{Fe}, \mathrm{Ca}$ and $\mathrm{P}$ possibly due to competition for sorption site, masking and the formation of insoluble complexes.
\end{abstract}

Keywords: Insoluble Complexes, Plant Nutrient Uptake, Soil, Heavy Metals

\section{Introduction}

Fluted pumpkin (Telfairia occidentalis) is known as Ugu plant in Nigeria. It is one of the most consumed vegetable in West African countries such as Nigeria, Ghana and Sierre Leone [1]. The nutritional constituent and value of Telfairia occidentalis plant differs, with higher concentration of nutrients in seeds than present in leaves [2]. Research has shown an estimate of $29 \%$ protein, $20 \%$ vitamins and $18 \%$ fat are contained in each seed of Telfairia occidentalis [3]. Telfairia occidentalis is a versatile vegetable, thus, can be used for many purposes. It is leafy, with a dark green coloration due to its high chlorophyll content. In a research to ascertain the effect of fluted pumpkin seed oil on semen and testis of animals, [4] proposed a reduced lipid peroxidation and an enhanced fluidity of cell membranes, thus, reducing sperm motility, replace damaged testicles and enhances spermatogenesis. This is because fluted pumpkin seed oil contains essential attributes such as vitamin A, oleic acids which suppresses lipid peroxidation [4]. A protective effect on the testis was observed on administration of extract of Telfairia occidentalis leaves at low concentrations [5]. Telfairia occidentalis also contains compounds such as oxalic acids, glycosides, saponins, alkaloids and flavonoids, Telfairia occidentalis seeds are enriched with edible plant oil having low saponification value than palm oil with high concentration of unsaturated fatty acids [6]. Studies has shown that Telfairia occidentalis seed oil are used in making margarine and cooking oil, these accounts for the large scale production of Telfairia occidentalis in Nigeria [7]. All these abilities possessed by Telfairia occidentalis are due to its nutritive constituents.

However, if there is no efficient uptake of soil mineral (nutrients), these distinguishing nutrients of Telfairia occidentalis would not be present. Research has shown that nutrients in soil can be prevented from uptake in plants [8]. Interaction with metal atoms resulting to masking, complexation and precipitate formation are just to mention but a few chemical factors which could prevent these 
nutrients from uptake. Metal toxicity play a major role in preventing the uptake of nutrient by plant, but this occur at certain concentration [8]. This implies that at certain concentration, some metallic nutrients become poisonous, especially when it has exceeded its permissible limit. This study investigated the impact of chromium on nutrient uptake ability of Telfairia occidentalis, and the impact of varying the concentration of chromium on nutrient uptake of Telfairia occidentalis. The study also examines the association between metallic nutrient toxicity and plant growth and maturity.

\section{Materials and Method}

\subsection{Experimental Design}

The impact of chromium on nutrient uptake capacity of Telfairia occidentalis was investigated by adopting a pot experiment. Varying concentrations of chromium (III) nitrate nonahydrate $\left[\mathrm{Cr}\left(\mathrm{NO}_{3}\right)_{3} .9 \mathrm{H}_{2} \mathrm{O}\right]$ were added to the soil and its effect was observed for 3 weeks. Stratified sampling method was used; soil sample were collected from the stratum containing the top soil, rich in mineral and organic matter. A total of 33 different pots were used in this study. The pot experiment consist of 10 different concentrations of chromium salt, ranging from $0.5 \mathrm{ppm}, 1.0 \mathrm{ppm}, 1.5 \mathrm{ppm}, 2.0$ ppm, 2.5 ppm, 3.0 ppm, 3.5 ppm, 4.0 ppm, $4.5 \mathrm{ppm}$, and 5.0 ppm. These concentrations of chromium added to each pot were studied relative to pots containing no additional chromium salt marked as control as shown in the plates. Maximum uptake of nutrients from the soil was determined. All analysis was done in triplicates.

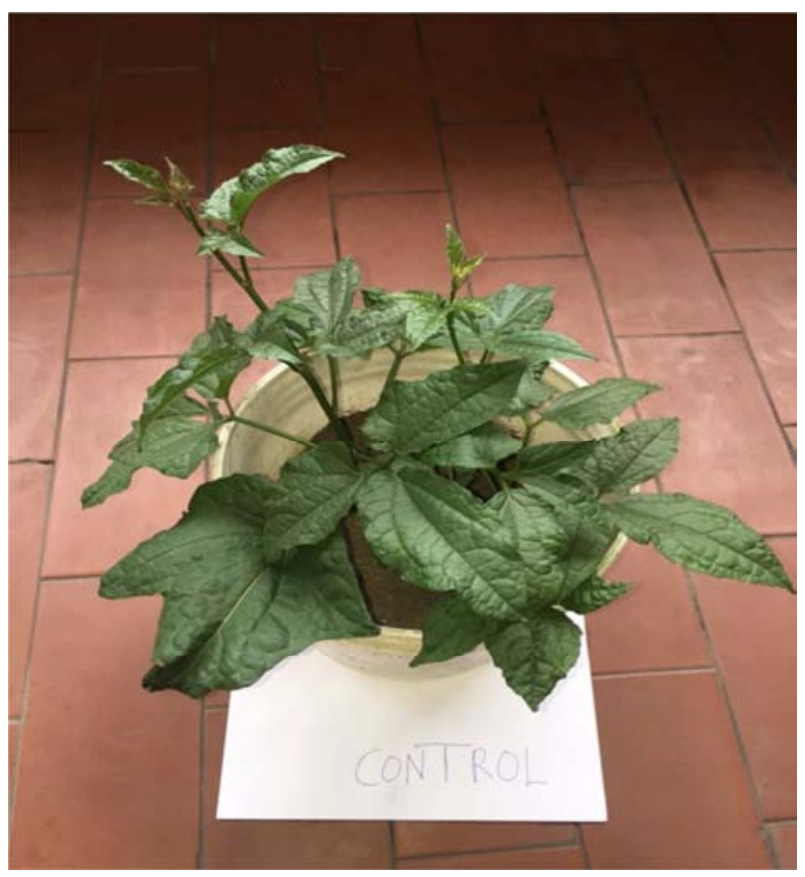

Figure 1. Control.

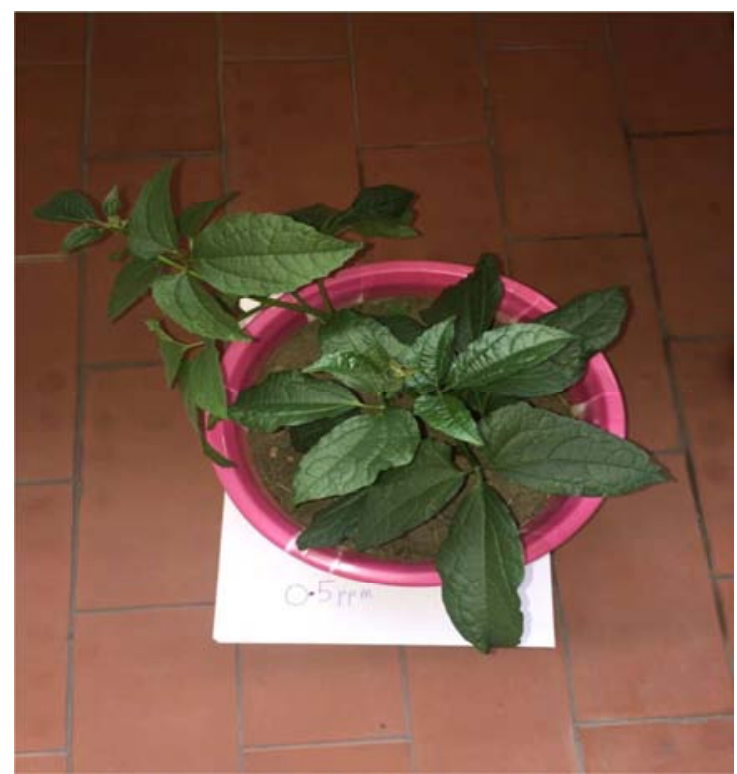

Figure 2. Effect of $0.5 \mathrm{ppm}[\mathrm{Cr}(\mathrm{NO} 3) 2.9 \mathrm{H} 2 \mathrm{O}]$ on nutrient uptake capacity of Telfairia occidentalis.

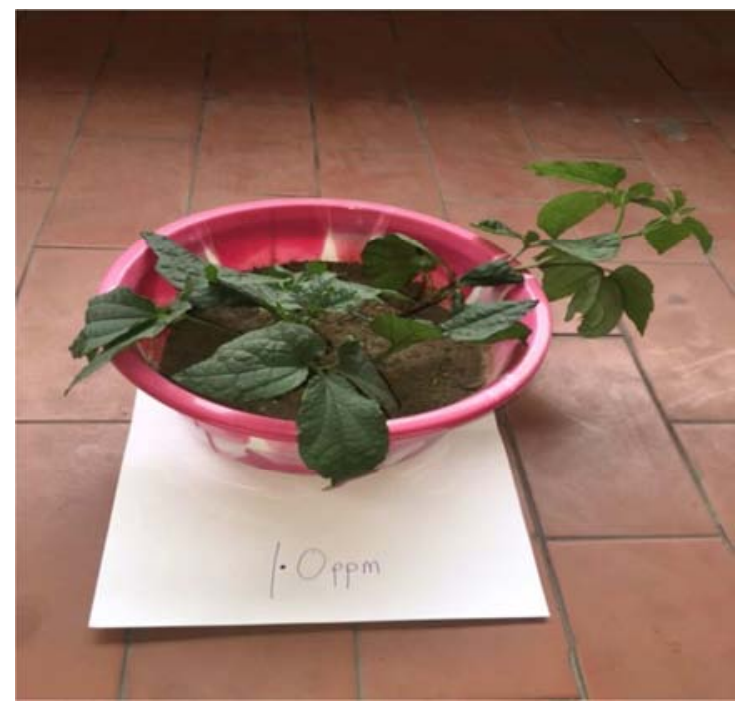

Figure 3. Effect of $1.0 \mathrm{ppm}\left[\mathrm{Cr}\left(\mathrm{NO}_{3}\right)_{2} .9 \mathrm{H}_{2} \mathrm{O}\right]$ on nutrient uptake capacity of Telfairia occidentalis.

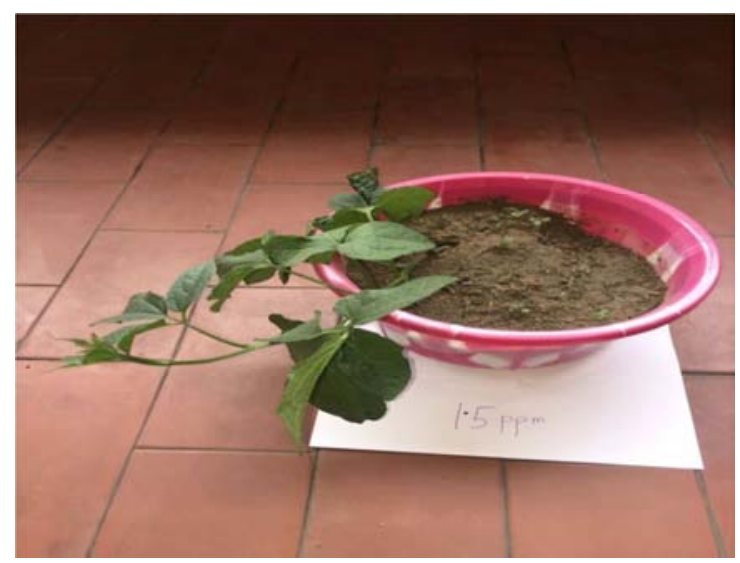

Figure 4. Effect of $1.5 \mathrm{ppm}\left[\mathrm{Cr}\left(\mathrm{NO}_{3}\right)_{2} .9 \mathrm{H}_{2} \mathrm{O}\right]$ on nutrient uptake capacity of Telfairia occidentalis. 


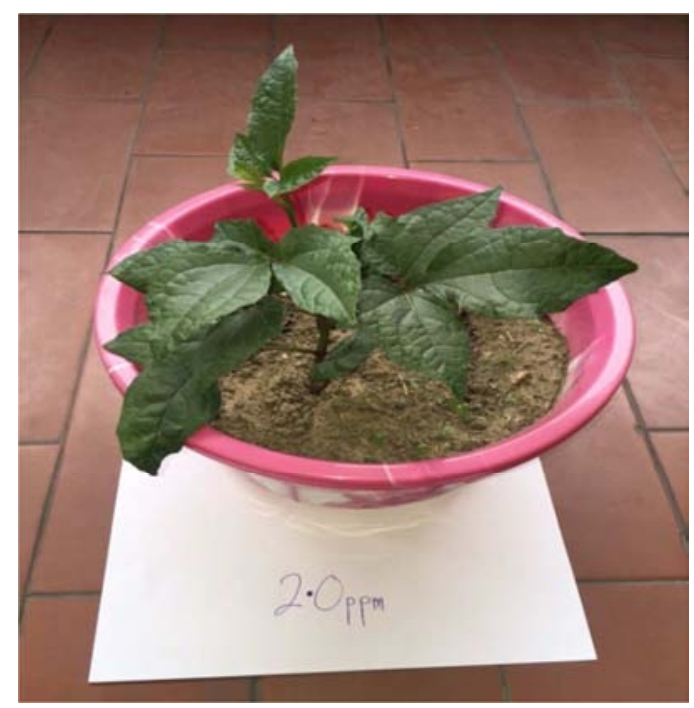

Figure 5. Effect of $2.0 \mathrm{ppm}\left[\mathrm{Cr}\left(\mathrm{NO}_{3}\right)_{2} .9 \mathrm{H}_{2} \mathrm{O}\right]$ on nutrient uptake capacity of Telfairia occidentalis.

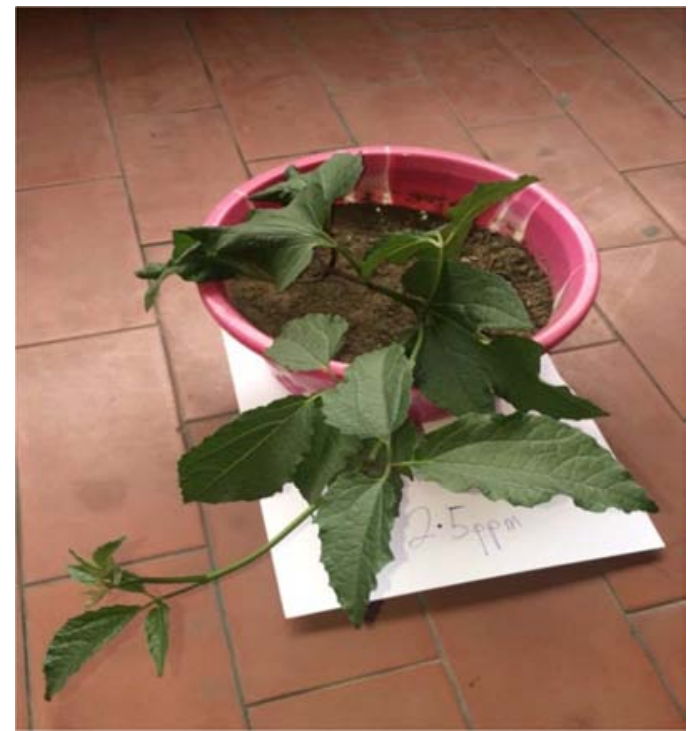

Figure 6. Effect of $2.5 \mathrm{ppm}\left[\mathrm{Cr}\left(\mathrm{NO}_{3}\right)_{2} .9 \mathrm{H}_{2} \mathrm{O}\right]$ on nutrient uptake capacity of Telfairia occidentalis.

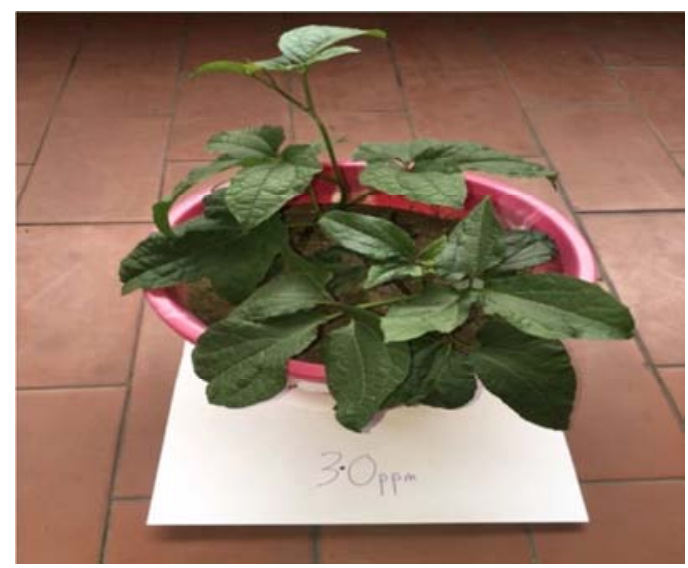

Figure 7. Effect of $3.0 \mathrm{ppm}\left[\mathrm{Cr}\left(\mathrm{NO}_{3}\right)_{2} .9 \mathrm{H}_{2} \mathrm{O}\right]$ on nutrient uptake capacity of Telfairia occidentalis.

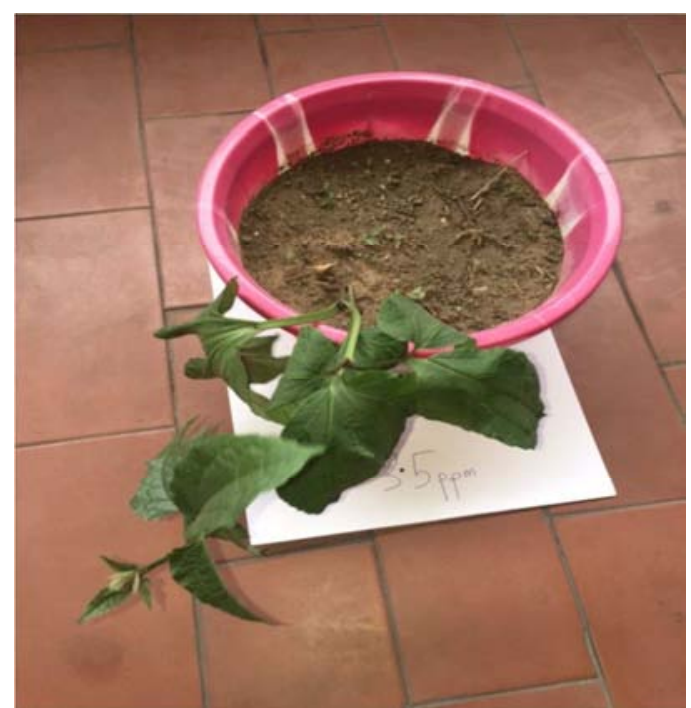

Figure 8. Effect of $3.5 \mathrm{ppm}\left[\mathrm{Cr}\left(\mathrm{NO}_{3}\right)_{2} .9 \mathrm{H}_{2} \mathrm{O}\right]$ on nutrient uptake capacity of Telfairia occidentalis.

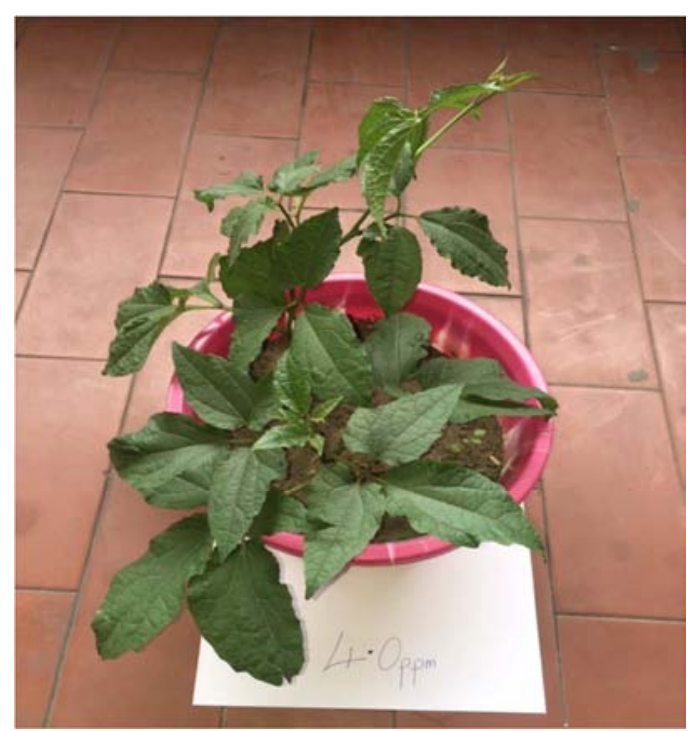

Figure 9. Effect of $4.0 \mathrm{ppm}\left[\mathrm{Cr}\left(\mathrm{NO}_{3}\right)_{2} .9 \mathrm{H}_{2} \mathrm{O}\right]$ on nutrient uptake capacity of Telfairia occidentalis.

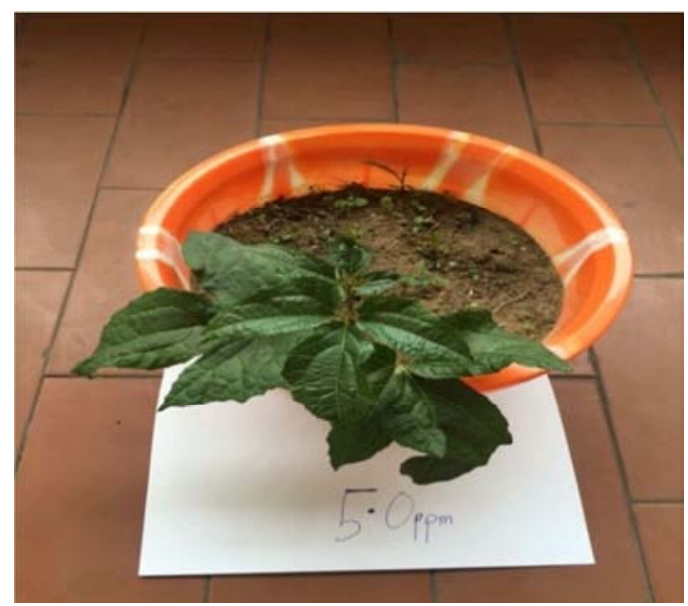

Figure 10. Effect of $5.0 \mathrm{ppm}\left[\mathrm{Cr}\left(\mathrm{NO}_{3}\right)_{2} .9 \mathrm{H}_{2} \mathrm{O}\right]$ on nutrient uptake capacity of Telfairia occidentalis. 


\subsection{Fluted Pumpkin Seed Preparation}

Fluted pumpkin (Telfairia occidentalis) seeds used in this research were obtained from Rivers State Agricultural Development Program (RSADP), located at Rumuodumanya, opposite Obio/Akpor Local Government secretariat, Rivers State, Nigeria. The fluted pumpkin seeds were initially soaked in alcohol for 30 seconds in other to kill microorganisms (pathogen) and subsequently, rinsed with distilled water before sowing in a plastic pot at the rate of two seedlings per pot [9].

\subsection{Soil Preparation}

To each pot containing $500 \mathrm{~g}$ of soil, $250 \mathrm{ml}$ chromium nitrate solution (with concentrations of $0.5 \mathrm{ppm}, 1.0 \mathrm{ppm}, 1.5$ ppm, $2.0 \mathrm{ppm}, 2.5 \mathrm{ppm}, 3.0 \mathrm{ppm}, 3.5 \mathrm{ppm}, 4.0 \mathrm{ppm}, 4.5 \mathrm{ppm}$ and $5.0 \mathrm{ppm}$ ) was added and mixed carefully with a hand trowel and was allowed to equilibrate for 24 hours before planting [8]. Each pot was tagged according to the amount of chromium solution added to the soil. All experiment was done in triplicate.

\section{4. pH Measurement}

Distilled water $(50 \mathrm{ml})$ was poured into $10 \mathrm{~g}$ air-dried soil sample in a $100 \mathrm{ml}$ conical flask. The sample was transferred to a plastic container, cocked, placed on a shaker for 1 hour, and filtered using whatman filter paper number 42 . The filtrate was analyzed using analog $\mathrm{pH}$ meter after calibration. Two calibrations were made using buffer solution at $\mathrm{pH}$ of 4.01 and 7.00 at $20^{\circ} \mathrm{C}$

\subsection{Soil Analysis}

Soil samples were obtained prior to planting and after planting to determine the nutrients uptake by Telfairia occidentalis. A simple soil digestion was performed. An airdried soil sample was grinded in a mortar to obtain a fine grain. $3 \mathrm{~g}$ each of the fine grain were weighed into a beaker, a $30 \mathrm{ml}$ aqua regia containing 1:3 ratio of concentrated nitric acid $\left(\mathrm{HNO}_{3}\right)$ and hydrochloric acid $(\mathrm{HCl})$ was added to the sample in a fume cardboard and heated for about 2 hours to liberate the analyte molecules $[10 ; 11]$. Both $\mathrm{N}$ and $\mathrm{P}$ were determined as percentage nitrate and phosphate using the Hach 3900 Dr Spectrophotometer, while all other mineral element was determined using flame Atomic Absorption Spectrophotometer (AAS).

\section{Results}

Table 1. Soil chemical parameters before cropping.

\begin{tabular}{ll}
\hline Parameters & values \\
\hline $\mathrm{pH}$ & 5.09 \\
$\%$ Nitrogen $(\mathrm{N})$ & 15.329 \\
$\%$ Phosphorus $(\mathrm{P})$ & 14.836 \\
Potassium $(\mathrm{K})$ & $1145.184 \mathrm{mg} / \mathrm{kg}$ \\
Calcium $(\mathrm{Ca})$ & $285.656 \mathrm{mg} / \mathrm{kg}$ \\
Iron $(\mathrm{Fe})$ & $251.096 \mathrm{mg} / \mathrm{kg}$ \\
Magnesium $(\mathrm{Mg})$ & $27.694 \mathrm{mg} / \mathrm{kg}$ \\
Chromium $(\mathrm{Cr})$ & $24.776 \mathrm{mg} / \mathrm{kg}$ \\
\hline
\end{tabular}

Morphological Characterization

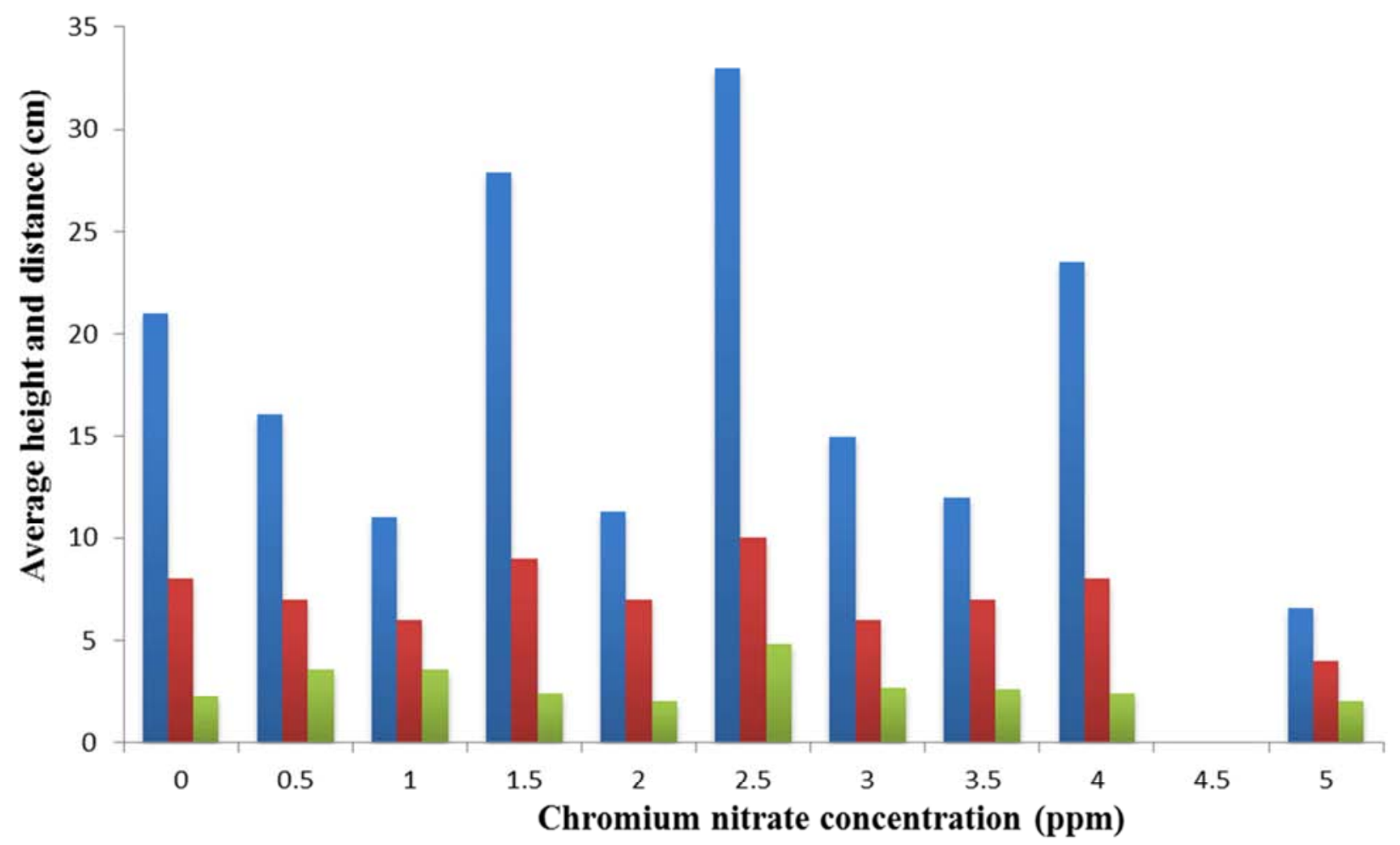

Figure 11. Growth parameters of Telfairia occidentalis after three weeks of planting, consisting of the average height (cm) (blue), average number of leaves (red) and average distance between nodes (cm) (green). 


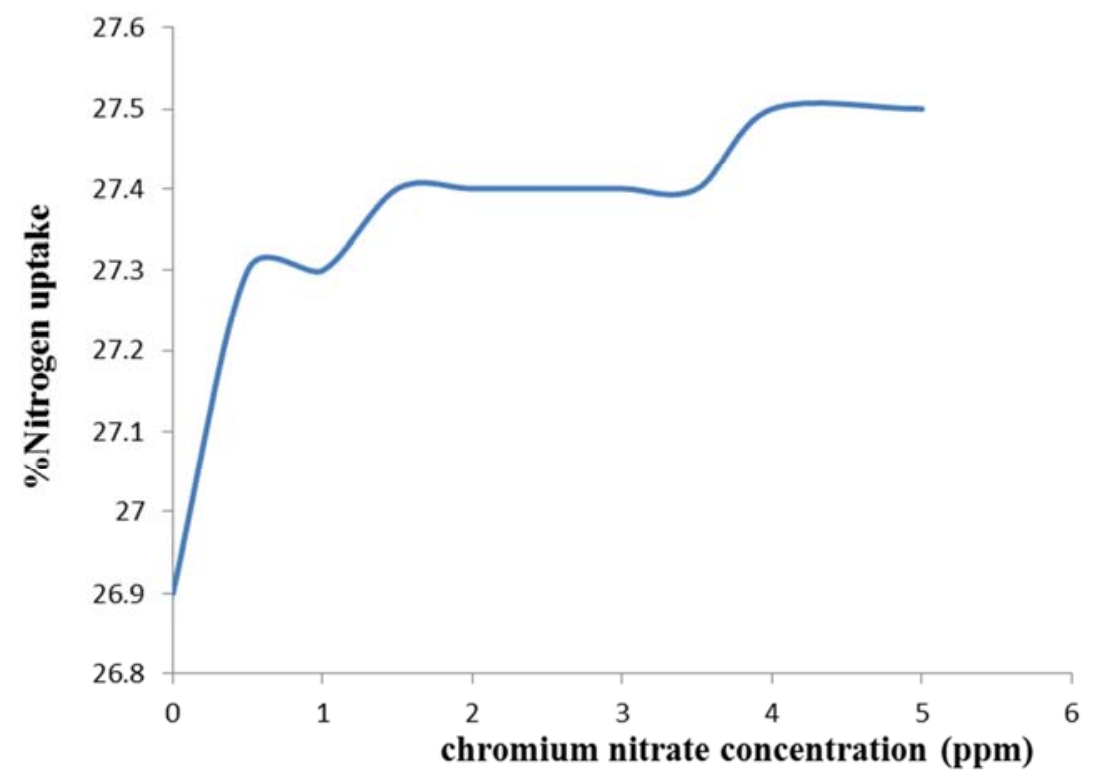

Figure 12. Impact of chromium nitrate on nitrogen uptake by Telfdairia occidentalis.

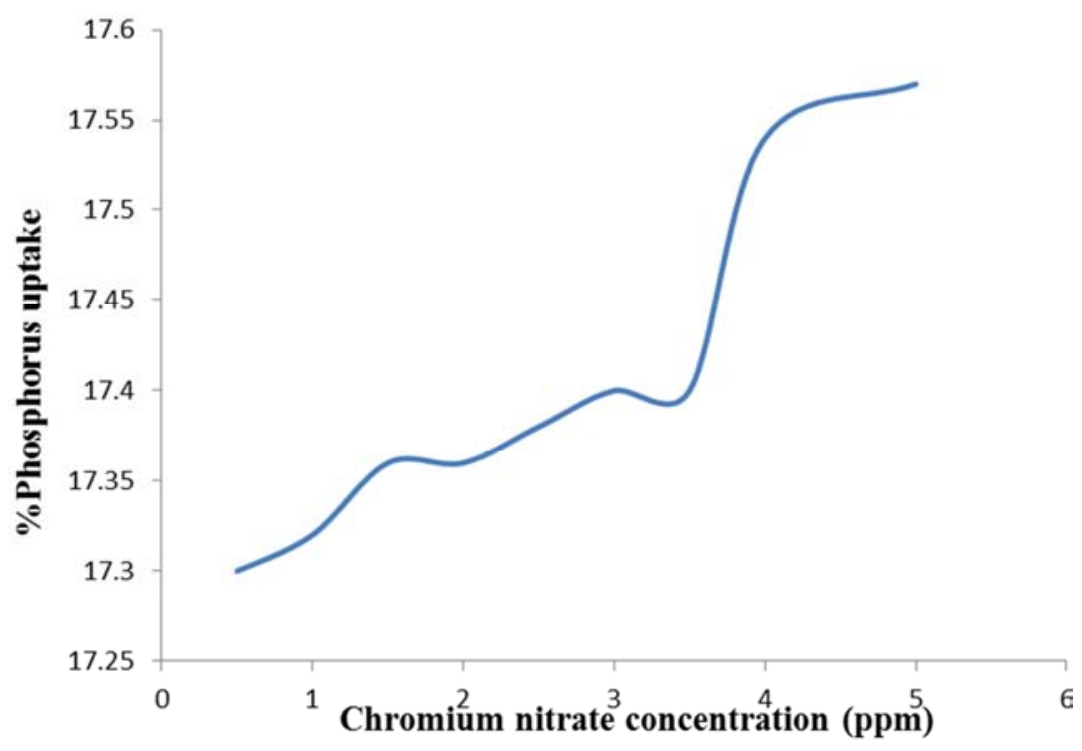

Figure 13. Impact of chromium nitrate on phosphorus uptake by Telfdairia occidentalis.

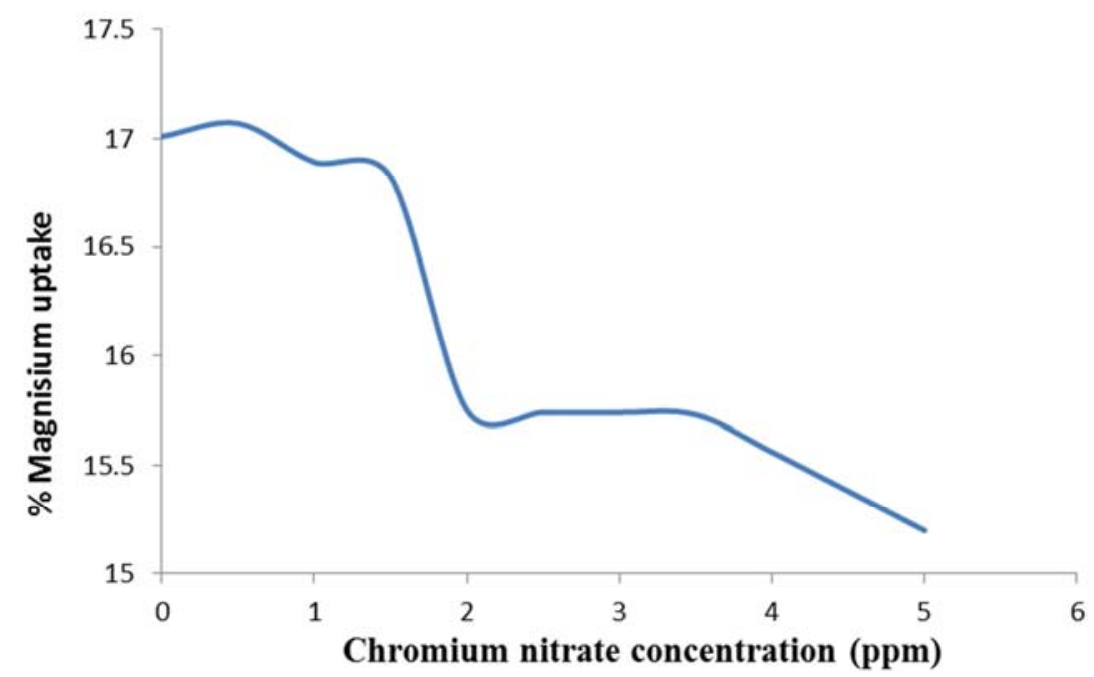

Figure 14. Impact of chromium nitrate on magnesium uptake by Telfdairia occidentalis. 


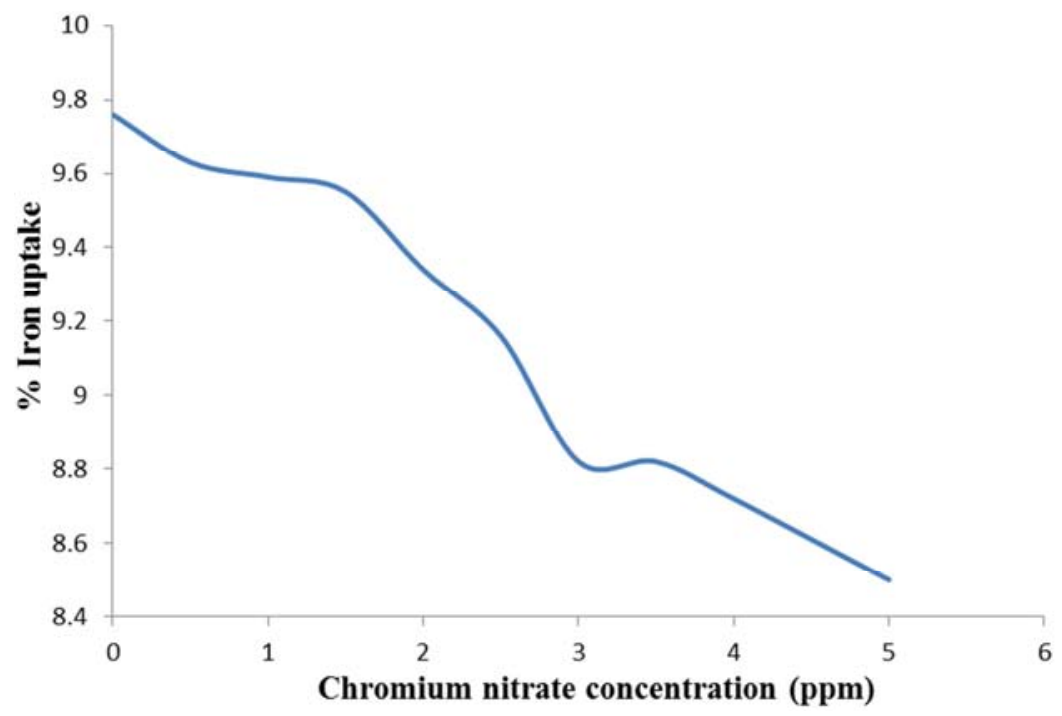

Figure 15. Impact of chromium nitrate on iron uptake by Telfdairia occidentalis.

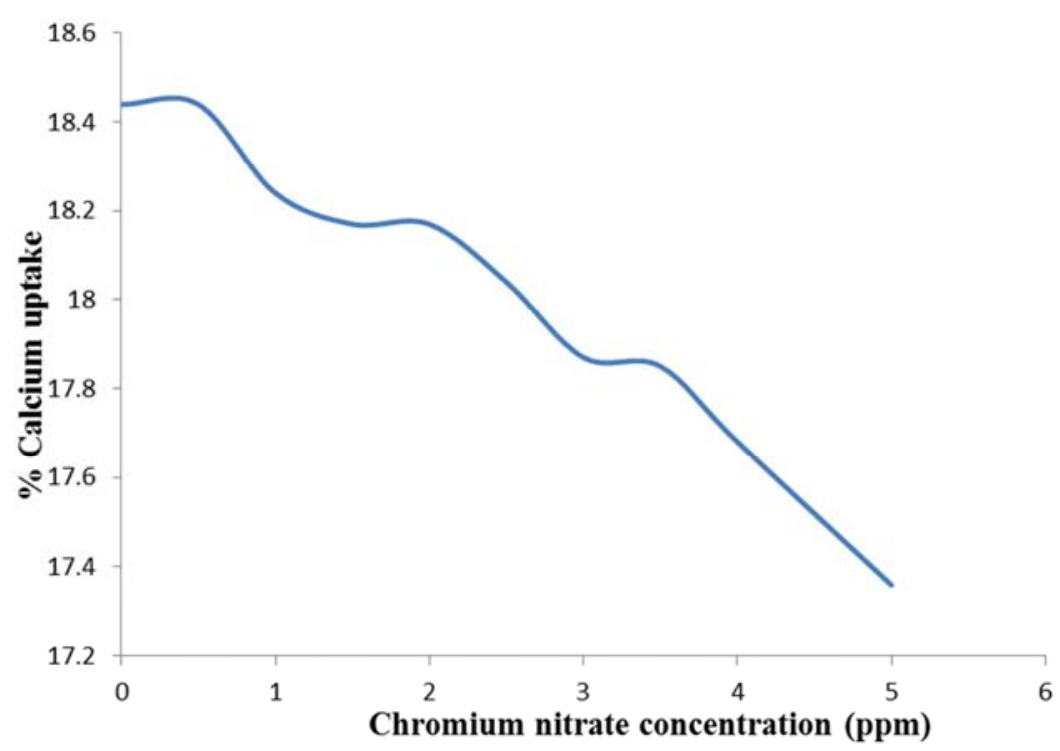

Figure 16. Impact of chromium nitrate on calcium uptake by Telfdairia occidentalis.

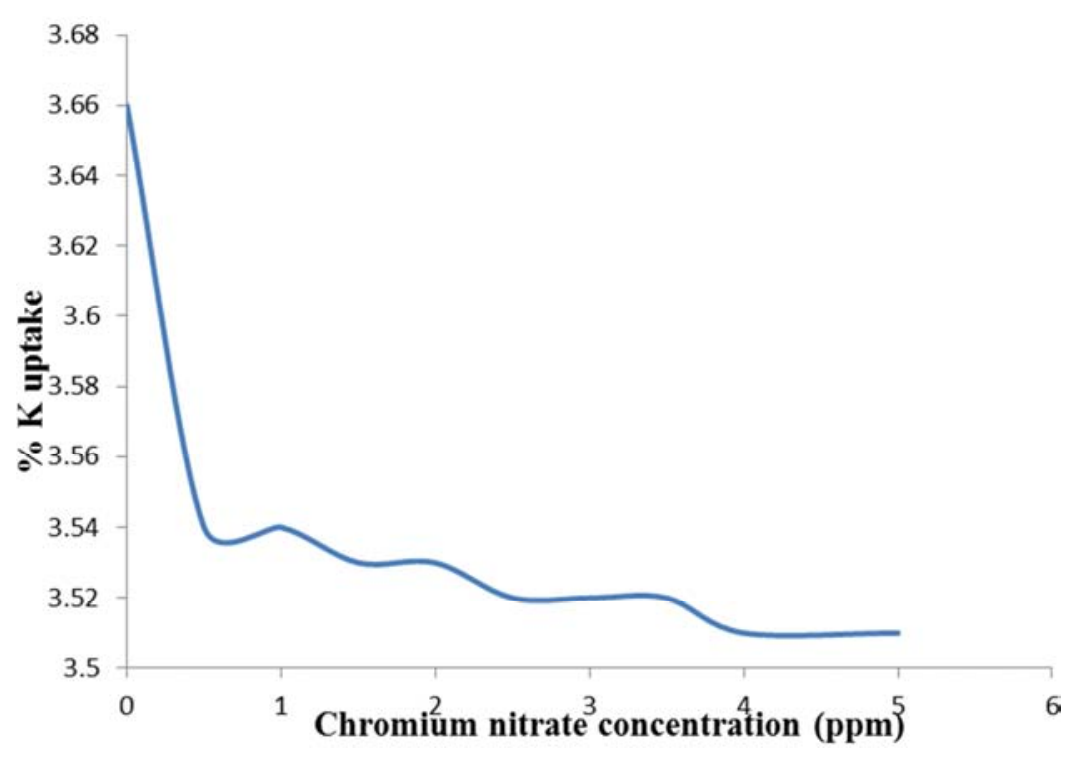

Figure 17. Impact of chromium nitrate on potassium uptake by Telfdairia Occidentalis. 


\section{Discussion}

The pre-cropping chemical features of the soil are presented in Table 1. The concentrations of the chemical parameters in the soil were $15.329 \%, \mathrm{~N} ; 14.836 \%, \mathrm{P}$; $1145.18 \mathrm{mg} / \mathrm{kg}, \mathrm{K} ; 285.656 \mathrm{mg} / \mathrm{kg}, \mathrm{Ca} ; 251.096 \mathrm{mg} / \mathrm{kg}, \mathrm{Fe}$; $27.694 \mathrm{mg} / \mathrm{kg}, \mathrm{Mg}$ and $24.77 \mathrm{mg} / \mathrm{kg}$, Cr. The soil was classified as sandy loam, rich in organic matter and having a partially acidic $\mathrm{pH}$ of 5.09, just below the neutral $\mathrm{pH}$ range.

After a growth period of three weeks, the physical growth and development of the plant were examined. The average number of leaves, average distance between nodes and the average height of triplicates for each concentration were measured in centimeter using a transparent meter rule. The result is presented in Figure 11. The average height, average number of leaves and average distance between nodes for the control that contains no additional chromium were $21.0 \mathrm{~cm}$, $8.0 \mathrm{~cm}$ and $2.3 \mathrm{~cm}$ respectively. At low chromium concentration such as $0.5 \mathrm{ppm}, 1.0 \mathrm{ppm}$ and $1.5 \mathrm{ppm}$ the respective average number of leaves of Telfairia occidentalis was 7,6 and 9, relative to control with an average of 8 leaves. The lowest number of leaves was reported at $5 \mathrm{ppm}$ with an average of 4 leaves, and the highest number of leaves was reported at $2.5 \mathrm{ppm}$ with an average of 10 leaves. Similar trend was observed on the average height and average distance between nodes. At low chromium concentration such as $0.5 \mathrm{ppm}$ and $1.5 \mathrm{ppm}$ the respective average height of vine was $16.1 \mathrm{~cm}$ and $27.9 \mathrm{~cm}$. The average height of vine was reported to be longer at $2.5 \mathrm{ppm}$ as $33.0 \mathrm{~cm}$, but was gradually dropped to $23.5 \mathrm{~cm}$ at $4.0 \mathrm{ppm}$ and $6.6 \mathrm{~cm}$ at $5.0 \mathrm{ppm}$. The average distance between nodes was reported to be $3.6 \mathrm{~cm}$ at both $0.5 \mathrm{ppm}$ and $1.0 \mathrm{ppm}$ relative to control with an average distance of $2.3 \mathrm{~cm}$. The average distance was reported to be high at $2.5 \mathrm{ppm}$ as 4.8 $\mathrm{cm}$ and low at $5.0 \mathrm{ppm}$ as $2.0 \mathrm{~cm}$. The common trend in the physical growth and development of Telfairia occidentalis in which high growth parameters were observed at $2.5 \mathrm{ppm}$ in contrast to higher chromium concentration as shown in figure 3.1 may occur as a result of the inhibition of nutrient from uptake by chromium on Telfairia occidentalis. At high chromium nitrate concentration competition for sorption site and formation of insoluble chromium compounds may occur with plant nutrients, hence reducing the available nutrients and the uptake of essential ions.

Increasing chromium amount in the soil did not have a high impact on nitrogen uptake by Telfairia occidentalis in soil, as shown in Figure 12 a percentage uptake of $26.9 \%$ was recorded at $0.00 \mathrm{ppm}$ chromium, $27.3 \%$ and $27.5 \%$ was recorded in $0.5 \mathrm{ppm}$ and $5.0 \mathrm{ppm}$ chromium correspondingly. Although a gradual rise in the uptake of nitrogen was noticed as the amount of chromium increased, this could be as a result of the increasing addition of soluble nitrate from chromium nitrate into the soil. Recall that the compound of chromium used in this experiment is chromium nitrate, also recall that the basic medium in which nitrogen uptake is done by plant is through the soluble nitrate and ammonium ion.
Therefore, a rise in the amount of chromium nitrate available for uptake also increases the possibility of nitrate uptake. This may account for the continuous rise in nitrogen uptake as the concentration of chromium nitrate rises.

As shown in Figure 13 no observable impact on phosphorus (phosphate) uptake was observed on increasing concentration of chromium nitrate, an uptake of $17.30 \%$ was recorded at $0.50 \mathrm{ppm}$, and $17.38 \%$ at $2.5 \mathrm{ppm}$. This could be as a result of less competition for sorption site due to differences in ionic size and type. Chromium is usually available as chromium cation $\left(\mathrm{Cr}^{3+}\right.$ and $\left.\mathrm{Cr}^{2+}\right)$ while phosphorus is available as phosphate. Although, it is possible for the chromium to form chromium (III) phosphate complex with the phosphate ions, such as $\mathrm{CrPO}_{4}, \mathrm{CrPO}_{4} .4 \mathrm{H}_{2} \mathrm{O}$, $\mathrm{CrPO}_{4} \cdot 6 \mathrm{H}_{2} \mathrm{O}$, and usually acid soluble due to chromium exchange potential with the protons of the acid but forms precipitate in aqueous medium. Similar observation was made by [12]. The possibility of chromium to form complexes lies in its incompletely filled $d$-orbitals, hence can easily accept lone pairs of electrons from the electron rich phosphate ion, thus forming complexes. The formation of such complex as chromium (III) phosphate could inhibit the uptake of phosphate by reducing the available phosphate molecules for plant uptake. This was probably not observed since the soil used in this experiment were slightly acidic, resulting in solubility of chromium (III) phosphate complex.

Increasing concentration of chromium slightly affected magnesium uptake as shown in Figure 14. At lower concentration of chromium such as $0.5 \mathrm{ppm}$ and $1.0 \mathrm{ppm}$, high uptake of magnesium was noticed, in sharp contrast to increasing chromium concentration such as at $5 \mathrm{ppm}$. At 0.5 $\mathrm{ppm}$ chromium concentration, an uptake of $4.728 \mathrm{mg} / \mathrm{kg}$ was recorded which is greater than the uptake of magnesium at $5.0 \mathrm{ppm}$ chromium nitrate with an uptake of $4.209 \mathrm{mg} / \mathrm{kg}$. The decreasing contraction in magnesium uptake as the concentration of chromium increases could probably be due to competition for sorption site as a consequence of the common ion effect. Recall that plants absorb nutrients in ionic forms, plant absorb magnesium and chromium in the form of $\mathrm{Mg}^{2+}$ and $\mathrm{Cr}^{2+}$ respectively. Coupled with this is the competition with other nutrients in the form of cations as reported in [13]. Hence, competition for sorption site may occur since magnesium and chromium have similar ion. Increasing concentration of chromium slightly affected (not intense) magnesium uptake possibly due to the relative abundance of $\mathrm{Cr}^{2+}$ in nature, although $\mathrm{Cr}^{2+}$ may be more available by the oxidation or reduction of $\mathrm{Cr}^{+}$and $\mathrm{Cr}^{3+}$ respectively, but the rate is very slow since it is a biochemical transformation.

Increasing chromium nitrate concentration was observed to have marked effect on iron uptake by Telfairia occidentalis. As shown in Figure 15, the result obtained at lower chromium nitrate concentration shows an observable decrease in iron uptake with respect to the result gotten at higher chromium nitrate concentration. At $0.5 \mathrm{ppm}$ chromium nitrate, an uptake of $24.177 \mathrm{mg} / \mathrm{kg}$ of iron was 
recorded which is significantly different from that obtained at 5 ppm $(21.337 \mathrm{mg} / \mathrm{kg})$. This may be due to competition for sorption site due to common ion effect. This is similar to the effect observed on magnesium uptake although more pronounced. This may be due to greater stability and abundance of $\mathrm{Cr}^{3+}$ which readily compete with $\mathrm{Fe}^{3+}$ for sorption site, hence reducing the uptake of iron by Telfairia occidentalis. Additionally, $\mathrm{Cr}^{3+}$ from chromium nitrate and $\mathrm{Cr}^{3+}$ obtained by the reduction of $\mathrm{Cr}^{4+}$ or oxidation of $\mathrm{Cr}^{2+}$ by microorganism in the root of Telfairia occidentalis increases the availability of $\mathrm{Cr}^{3+}$, hence increases competition with $\mathrm{Fe}^{3+}$ and $\mathrm{Fe}^{2+}$ for sorption site.

An observable decrease in calcium uptake by Telfairia occidentalis on increase in chromium concentration was observed. At low concentration of chromium nitrate, high uptake of calcium by Telfairia occidentalis was observed as shown in figure 16. An uptake of $52.669 \mathrm{mg} / \mathrm{kg}$ and 52.099 $\mathrm{mg} / \mathrm{kg}$ of calcium by Telfairia occidentalis was recorded at $0.5 \mathrm{ppm}$ and $2.0 \mathrm{ppm}$ chromium nitrate respectively. On the contrary at high chromium concentration, the uptake of calcium by Telfairia occidentalis was seen to decrease. An uptake of $49.585 \mathrm{mg} / \mathrm{kg}$ of calcium was recorded at $5.0 \mathrm{ppm}$ chromium concentration. The reduction in uptake amount on increase in concentration may be due to the common ion effect, which creates competition for sorption site. $\mathrm{Cr}^{2+}$ and $\mathrm{Ca}^{2+}$ both compete at the rhizosphere of Telfairia occidentalis for uptake. This was also reported in [13]. Similar observation was observed on the impact of chromium on magnesium uptake by Telfairia occidentalis; and this may be true since both magnesium and calcium occur in the same group of the periodic table, hence show close connection in both physical and chemical properties. Therefore, to achieve high uptake of calcium by Telfairia occidentalis a low chromium concentration is required.

The plot in figure 17 shows little impact on potassium uptake. This may be due to the different available forms of both ions in soil (potassium ions and chromium ions). Potassium is readily available for plant uptake as $\mathrm{K}^{+}$, but the corresponding chromium ion $\left(\mathrm{Cr}^{+}\right)$is rarely available for uptake, hence, competition for sorption site barely occur. Although, $\mathrm{Cr}^{2+}$ and $\mathrm{Cr}^{3+}$ are readily available and may also compete with $\mathrm{K}^{+}$for sorption site since they are also cations, but the competition may not be as high as expected of $\mathrm{Cr}^{+}$if it were to be available. Recall that enzymatic reactions in the cell require that the substrate fits in properly on the binding site. The ionic radii of $\mathrm{K}^{+}$and $\mathrm{Cr}^{+}$are close and differ significantly with the ionic radii of $\mathrm{Cr}^{3+}$, the ionic radii of $\mathrm{K}^{+}$is $138 \mathrm{r}$ and is close to the atomic radii of $\mathrm{Cr}(129 \mathrm{r})$ which is the closest to $\mathrm{Cr}^{+}$but significantly different with $\mathrm{Cr}^{3+}(62 \mathrm{r})$, hence may not fit in or bind properly to activate an enzymatic reaction. Hence, the contrast in ionic radii and size may add to the insignificance of chromium nitrate on potassium uptake.

\section{Conclusion}

The impact of chromium nitrate on plant nutrient uptake by Telfairia occidentalis has been studied and the results reported.
The result showed no specific uptake trend in all nutrients considered, but had varying effect on the uptake of individual nutrient. The greater the amount of chromium in soil, the lower the uptake of nutrient by Telfairia occidentalis. Increasing chromium nitrate amount may not readily hinders the uptake of nitrogen since a gradual increase in soluble nitrate is made available to the soil for uptake, although this may not be the case at extreme chromium condition since chromium have high tendency to alter cell reaction which may result to the death plant. Increasing chromium concentration can hinder the uptake of plant nutrients by either forming insoluble compounds with the nutrients in the soil, thus, rendering the nutrient unavailable for plant uptake or damaging plant cells by interacting with cell compounds and components like protein, DNA, ATP, and ADP, hence causing conformational changes that can lead to the death of plant. Competition for sorption sites occur due to common ion effect in which nutrient molecules with similar ions compete for uptake. This may lead to a deficiency of some nutrients in plant even though that nutrient may be present in the soil as a result of low uptake.

\section{References}

[1] Nkang, A., Omokaro, A., Egbe, A., \& Amanka, G., (2003). Variation of fatty acid proportion during desiccation of Telfairia occidentalis seeds harvested at physiological and agronomic maturity. African Journal of Biotechnology 2 (2): 33-39.

[2] Oyekunle, O. J., \& Abosede, O. T., (2012). Growth, yield and nutritional composition of fluted pumpkin (Telfairia occidentalis) as affected by fertilizer types in ogbomoso, south west Nigeria, Bulletin of Environment, Pharmacology and Life Sciences, 1 (9): 81-88.

[3] Akanbi, W. B., Adebouye, C. O., Togun, A. O., Ogunrinde, J. O., \& Adayeye, S. A., (2006). Growth, herbage and seed yield, and quality of Telfairia occidentalis influenced by cassava peel compost and mineral fertilizer, Would Journal of Agricultural Science, 3 (4): 508-516.

[4] Akang, E. N., Oremosu, A. A., Dosumu, O. O., Noronha, C. C., \& Okanlawon, A. O., (2010). The effect of Fluted Pumpkin (Telfairia occidentalis) seed oil on testis and semen parameters, Agriculture and Biology Journal of North America, 1 (4): 697-703.

[5] Saalu, L. C., Kpela, T., Benebo, A. S., Oyewopo, A. O., Anifowope, E. O., \& Oguntola, J. A., (2011). The dose dependent testiculoprotective and testiculotoxic potentials of Telfeiria occidentalis Hook $f$. leaves extract in rat, International Journal of Applied Research in Natural Products, 3 (3): 27-38.

[6] Ladeji, O., Okoye, Z., \& Ojobi, T., (1995). Chemical evaluation of the nutritive value of leaf of fluted pumpkin (Telfairia occidentalis), Food Chemistry, 53: 353-354.

[7] Odiaka, N. I., Akoroda, M. O., \& Odiaka, E. C., (2008). Diversity and production methods of fluted pumpkin (Telfairia occidentalis Hook F.); experience with vegetable farmers in Makurdi, Nigeria. African Journal of Biotechnology, 7 (8): 944-954. 
[8] Osu, C. I. \& Mark, O. O., (2016). Vanadium inhibition capacity on nutrient and heavy metal uptake by Cucumis sativa, Journal of American Science, 12 (10): 63-66.

[9] Iyagba, A. G., \& Offor, U. S., (2013). Phytoextraction of heavy metals by fluted pumpkin (Telfairia occidentalis Hook F.) planted on oil contaminated soil amended with sawdust and siam weed (Chromolaena odorata) leaves, International Journal of Agricultural Science and Soil Science, 3 (12): 422426.

[10] Alinnor, J. I. (2004). Estimation of trace elements in leaves of Talium triangulare (water leaf) and Varnonina amygdalina (bitter leaf) from major highways leading to Owerri. Nigerian J. Appl. Sci., 2: 255-261.
[11] Iyaka, Y. A. (2007). Concentration of $\mathrm{Cu}$ and $\mathrm{Zn}$ in some fruits and vegetables commonly available in North Central Zone of Nigeria. Electron. J. Environ. Agric. Food Chem., 6: 21502154.

[12] Nwonuala, A., \& Obiefuna, J., (2015). Yield and yield component of fluted pumpkin (Telfairia occidentalis Hook) Landrace, International Journal of Agriculture Innovations and Research, 4 (3): 421-425.

[13] Osu Charles I. And Isaac, Issac U.(2014). Effect Of Nickel Concentrations On Amaranthus Spinosus Uptake Of Nutrients And Heavy Metals In Soil. Journal Of Applied Phytotechnology In Environmental Sanitation, 3 (3): 87-91. 